Transmissible gastroenteritis in pigs :

selection in tissue culture (RP.TG cells) of TGE virus strains resistant at $\mathrm{pH} 2.0$ to digestive enzymes and attenuated for the new-born piglet

\author{
J.M. AYNAUD *, E. BOTTREAU*, A. BRUN *\%, P. VANNIER *** \\ * I.N.R.A., Laboratoire de Pathologie porcine, Nouzilly, 37380 Monnaie \\ :**: Rhône-Mérieux, 254, rue Marcel-Mérieux, 69007 Lyon \\ *:** Ministère de l'Agriculture, Direction de la Qualité, \\ Station de Pathologie porcine, 22440 Ploufragan
}

France

In order to improve oral immunization of the pregnant sow against transmissible gastroenteritis, two strains of TGE coronavirus were selected in tissue culture (RP.TG cells) by means of a large number of survivor selection cycles in stomach juice ( $\mathrm{pH}$ 1.5-2.5) collected from adult pigs. These two strains are characterized as follows in comparison with the initial D.52 strain or with the Purdue 115 strain :

1. Stability at $\mathrm{pH} 2.0$.

2. Higher resistance to digestive enzymes.

3. Small plaques only in ST cells.

4. Loss of virulence for the new-born piglet.

5. Immunogenicity (neutralizing antibody) in the new-born piglet.

Taking these properties into account, further experiments should be made to evaluate the capacity of these new virus strains to induce a lactogenic immunity against TGE in the sow, with a protective effect on the sucking piglet.

Transmissible gastroenteritis in pigs :

use of an inactivated oil emulsion vaccine for boosting the immunity in previously infected sows

\author{
J.M. AYNAUD *, P. VANNIER **, L. MARTAIN ***, R. CARIOLET ** \\ *I.N.R.A., Laboratoire de Pathologie porcine, Nouzilly, 37380 Monnaie \\ ** Ministère de l'Agriculture, Direction de la Qualité, \\ Station de Pathologie porcine, 22440 Ploufragan \\ *** Laboratoires C.O.G.L.A., 23-25, avenue Morane-Saulnier, \\ 92360 Meudon-la-Forêt \\ France
}

An oil emulsion vaccine against TGE was prepared using a virus suspension produced in tissue culture and inactivated by formaline. Intramuscular vaccinations of sows were performed in two herds (176 sows) which had been infected by TGE virus more than one year before.

Considering qualities of immunity following natural infection, the objective of the work was to try to give a new impetus to immunity in such herds using vaccination as a booster. After two vaccine injections the serological pattern of the herd was modified : the negative serological reaction disappeared, the proportion of highly positive serological reactions increased and a higher homogeneity was observed in the distribution of levels of neutralizing antibody reactions. 
In contrast, using protection tests in piglets against virulent challenge, there was no evidence for significant differences between litters of vaccinated sows (86 p. 100 of piglets were protected) and those of unvaccinated sows $(89$ p. 100 of piglets were protected). Our results suggest that passive protection given to piglets by lactogenic immunity following natural infection may last during the whole economic life of the sow. The interest of using the vaccination as a booster of mammary immune response and its epidemiological consequences are discussed.

\title{
Utilization of a new endectocide (ivermectin) for pigs Preliminary studies
}

\author{
J. FOREST $*$, A. RICHARD $* *$, A. APPERT $* * *$ \\ $*$ Etablissements Langlois, 35040 Rennes Saint-Jacques \\ * U.F.A.C., 95450 Vigny \\ *:*:M.S.D.-A.G.V.E.T., rue de la Ville-l'Evêque, 75008 Paris \\ France
}

The authors report the preliminary results obtained in France and in other countries with ivermectin - a new endectocide-active both against the main internal and external parasites — when used subcutaneously at the recommended dose of $0.3 \mathrm{mg} / \mathrm{kg}$ live weight.

Using infestations whether induced or natural, the experiments aimed at determining the dose range efficiency and the optimal level of the product, confirmed under field conditions. Ivermectin was highly effective on the major internal parasites present in France (Ascaris spp., Oesophagostomum spp., Hyostrongylus spp., Strongyloides spp., Metastrongylus spp.).

At the same dose level $(1.5 \mathrm{ml}$ of the commercial formulation per $50 \mathrm{~kg}$ live weight) ivermectin was highly effective in the treatment and the control of mange and lice. A progressive improvement was observed a few days after the treatment with disappearance of pruritus and of lesions due to serapings.

The safety of using ivermectin in pigs at several dose levels (single dose of $10 \times$, $50 \times, 100 \times$ the recommended level, standard or double doses during organogenesis or final gestation) with a special reference to breeding animals is emphasized.

These studies showed that use of ivermectin, even when doubling the recommended level, did not lead to any adverse effects in pregnant sows, boars or bacon pigs.

A specific study showed that ivermectin has no detrimental effect on the major economical parameters of breeding such as the number of born piglets, weaned pigiets, weight of piglets at farrowing and at 21 days, weaning-mating interval, weaning-fertilization interval, milk secretion.

Authors point out the value of ivermectin in sows for treatment and control of parasitism (in particular mange and lice) owing to its wide spectrum, conveniency and its safety in pregnant sows. 